\title{
Traces of a fortified hamlet. Iconography and urban development of San Valentino in Abruzzo Citeriore
}

\author{
Stefano Cecamore \\ Dipartimento di Architettura - Università degli Studi dell'Adriatico “G. d'Annunzio" Chieti-Pescara, Pescara, Italy, \\ stefano.cecamore@unich.it / stefanocecamore@gmail.com
}

\begin{abstract}
The paper proposes a reading of the possible urban development of the historic centre of San Valentino in Abruzzo Citerore starting from the analysis of its architectural heritage. The image of a fortified hamlet surrounded by walls, represented in a painting dating back to the mid-nineteenth century, appears in cartographic reliefs and representations accessible at the local and extra regional archives.

The reading of the current architectural set of givens, which are characterized by the continuous use of building techniques related to the processing of local limestones, seeks through comparison with the historic iconography to identify persistences and alterations of the urban fabric, tracing a possible developmental line of San Valentino in Abruzzo Citeriore from medieval castrum to Farnesiano fief up to the substantial interventions of modernization and revision of the historic center operated in the last century.

The requests of functional and formal changes occurring at the turn of the nineteenth and twenteeth century implicates the dismantling of the walls, the typological change of the original building and of the urban layout and the loss of the urban imagine resulting consolidated in the collective memory.

An awaking context of the main features of the historic and building development of this fortified reality in the Middle Adriatic area is today an indispensable step in this path of consciousness and awareness of the society regarding the urgent problem connected to the neglect and to the conservation of the historic centres.
\end{abstract}

Keywords: Iconography, historic centre, traditional building techniques.

\section{Introduction}

The morphological harsh and traditionally rural characteristics of Abruzzo leads it to be a structured settlement network through the fragile equilibrium between man and nature. The intended desire to live in valleys and mountain ridges and to overcome recurrent trauma of the disastrous events that have always affected the historic centres of the Apennine territory define the territorial construction events, whose traditional repertoire associated to "long life-span" building phenomena restores a century-old union between building techniques and local resources.
Particularly, the "stone culture" outlines the urban profiles of Abruzzo Citeriore with a predominant use of processing the compact limestone well known as the "gentile stone of the Maiella Mountain" continually applied from the classic period until the beginning of the twentieth century.

Indeed, the architectural heritage of San Valentino in Abruzzo Citeriore confirms these construction practices; the building scenario of the historic centre and the surrounding area is de- 
fined by the almost exclusive use of local limestones in a wide range of construction solutions.

\section{Castrum Petrae, from castle to town}

An agglomeration of architectural remains, construction aggregate and distinct rural buildings, nevertheless perceptively completed in an intensive setting of urban scenes woven with the same materials and closed by a surrounding wall.

It is the imagine of the castrum in stones mentioned by the sources, intended in its complexity as a progressively fortified residential perimeter; the same can again be seen in the painting by $\mathrm{S}$. Giannini (1848) preserved in the church of Santi Valentino e Damiano (Fig. 1) which gives an idealized but substantially faithful view of the various stratifications over the centuries to project a castle-town at the end of the nineteenth century.

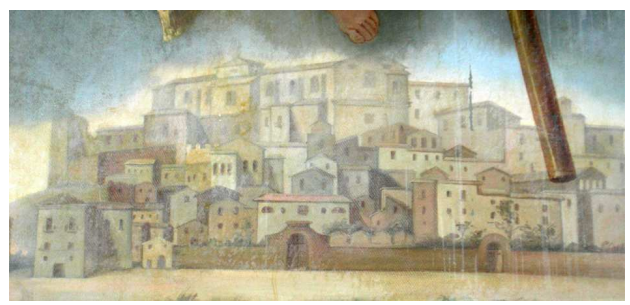

Fig. 1. Church of Santi Valentino e Damiano, detail of the painting painted by S. Giannini (Author, 2012).

Despite the numerous changes recently endured from fortifications and urban fabric it is possible, by overlapping the present cartography with the iconographic record available (Fig. 2) (Chiarizia, Latini, 2002, pp. 45-228, fig. 387), to distinguish the traces of the ancient defensive features which gave the country a guideline for the development characterized by concentric expansions along the eastern side of the primitive nucleus.

The outcome is the battlemented village surrounded by walls which recur in the description of Giustiniani in 1797 and resulting in some documents and maps from the end of the sixteenth century onwards.
Such is difficult to trace in the distinctive architectural features of the building, however, it is legible at urban level in those areas that are extended over blocks of land identified by road layouts forming a fusiform urban pattern interrupted by a secondary road system consisting of ramps and climbing roads.

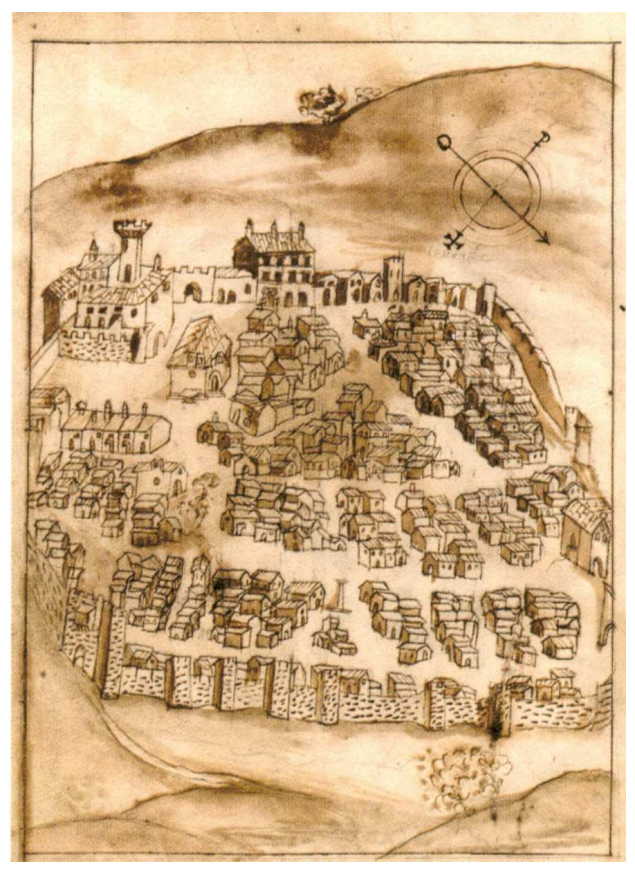

Fig. 2. 'Summario dell'Intrate che'l Serenissimo Signor Duca di Parma e Piacenza tiene nella provincia d'Abruzzo. Aquila ultimo gennaro 1593" (Chiarizia, Latini, 2002, fig. 387).

In some cases, the relatively recent thinning operations have changed the transversal lanes of the main building in open spaces and stairways; remarkable seventeenth-eighteenth century events associated to functional and formal modernization of the historic town are near the Mother church and few other buildings, worthy urbanistic constructions, such as Bottari Palazzo.

Overall, the typological updated restoration of the building complies with the review of the original building cells of the compact fabric of block buildings, mainly with no courtyard, in larger buildings including two, three levels, laid out in new façades and consistent in architectur- 
al language through the research of symmetries and approval of decorative elements.

Mostly compromised is the fortified trail that almost nothing preserves of the curtain walls, the latter absorbed by the construction of walled houses and subsequently of the Palazzi belonging to important landowners, and altered in the original layout by the expansion beyond the perimeter of the building complex of the Mother church, of the Palazzo di Pietro Troiano ${ }^{1}$ to the west and Palazzo Baiocco on the opposite side.

The latter, in proximity of Largo San Nicola, is probably the result of the combination of several elementary cells merged into a single body in response to the unexpected needs of public use of the new ruling class in the late nineteenth century. The building, which is structured in two forebuildings connected by a backward transversal wing, finds ennoblement in the volumetric system played on the juxtaposition of basement, terrace and compact block with central court that follows the natural slope of the site between Corso Umberto I and via Duca degli Abruzzi. Likewise, the external layout introduces innovative elements with respect to the surrounding urban fabric: the main façade, organized in two registers, appears defined by pilasters, stringcourse bands and cornices and allows direct access to the residential level through an ashlar portal surmounted by a balcony on cornices. On the opposite side, a long series of arches in stone ashlars alternating with pilasters defines the covered terrace building which raises the building compared to the opposite road axis. The arch with fastigium crowning and the wide gate of access define the perimeter of the original plant, changed after the insertion of commercial premises, small volume of services and a petrol station.

The central courtyard building is an exception in the panorama of the local traditional construction distinguishing the suburban Villa of the family (Varagnoli, Serafini, 2008, pp. 65-66) built approximately in the second half of the nineteenth century in Cannafischia; the building, in a total state of neglect, is placed in line with a wide water basin which was probably used for water supply and for agricultural use or simply for the "delights of the Villa" which seem to be more likely as it was called "holiday resort" as recorded in the General Revision of the Real Estate Registry in 1890. The general layout defers from the traditional rural building, two independent levels one on the other, the first floor was destined for foodstuff and livestock while the second was for residential use and had an external staircase which traced the typology of the building planned symmetrically with respect to the central axis and served by two internal staircases.

The setting, which is strictly mirrored-like, is divided into fourteen rooms per floor; on the first level there are barrel vaults with lowered lunettes, ribbed vaults and cross vaults; on the second level there are cloister vaults made with bricks-on-edge course. The load-bearing masonry, devoid of the original plaster, reveals the front in stone masonry arranged in subhorizontal courses with reinforced wedges and rubbles.

The decorative item, most of which is missing as a result of the collapses of covers and floors, is partly legible on the external fronts framed geometrically by full-height pilasters surmounted by capitals and festoons in Renaissance-style, as well as by stringcourses that delimit segmental profiles defined by block of ashlars and placed with outward curving bars on bracketed cornices.

\section{The "stone civilization"}

A common language sets public buildings and "minor" buildings together: construction techniques and materials belong to a traditional repertoire closely linked to the characteristics of the place.

The rough stones, found at the foot of the rocky walls of the Maiella, are used both in the external faces of the walls where the larger fragments of stone are positioned with their flat side at sight, as well as in the core of the building filled with rubbles and stone elements deriving from stone processing. A major interest shown is for the structures of the corners, limestone blocks have the shape of a parallelepiped, the material used has variable dimensions and they are bind 
together with abundant mortar in uneven courses generally assuming a horizontal development.

The use of traditional techniques and the custom to make use of exclusively local material is found in the constant reutilization of demolished material, recovered after the subsequent collapses due to earthquakes, and inserted inside the walls and external facings. Numerous shaped and decorated fragments are placed on the main fronts of the buildings to complete and ennoble the walls, brackets and architraves.

The most interesting construction elements are found in the upper part of the south-west area of the town, where Palazzo Farnese, the church of Santi Valentino e Damiano and Palazzo Troiani are now located. The area is identified as the core generator of the old fortified hamlet. The primordial structure can be traced back to the Norman era within the county of Manoppello, which has then evolved to the present San Valentino whose origins can be associated to the facts narrated in the Chronicon Casauriense and to the discovery of the remains of the saints Valentino e Damiano in the eleventh century (Luzio, 1990; Varrasso, 1992, p. 25 n.14, 31 n. 20).

The first bastion that had defense systems as well as sighting functions dates back to the Norman Riccardus Turgisii. Here there still survives an avant-corps of the guard in the southern tower of the current building. This structure is numbered in the Catalogus Baronum as a subfeudal vassal of Count Beomondo di Manoppello.

However, San Valentino had been subject to the influence of the abbey of San Clemente a Casuauria which in force of the donations during the years 1070, 1074 and 1075 claims the ownership in a constant tug of war with the Norman patricians. This until it erecting in 1337 when it became an independent county thanks to Corrado Acquaviva who took possession of it as the nephew of the last Turgisii, Francesca (Sorricchio, 1929, p. 40). The Benedictine monks wanted to have a direct control of the center that governs the entrance to the Lavino and Orta valleys, fundamental for the control of the entire Maiella, pushing them to include San Valentino among the properties which were engraved on the bronze doors of the abbey, although it does not appear as so in Pope's Celestine III letter.

The authority that allows San Clemente to exercise over the neighboring areas may have conditioned the structural evolution of the settlements imposing a model visible in other settlements, such as Castiglione a Casauria, which provided the adaptation in response to the increase of the structures existing, subject to the ecclesiastic settlement, however, impeding to build independent castle structures as compared to the area.

\section{From castrum to castle, from castle to pal- ace}

The problematic question regarding the foundations of the castle of San Valentino could be traced back to when there were aggregations of buildings of various kinds (ecclesiastical and feudal) surrounded by sets of walls. The heterogeneity still characterizes the complex which is the result of numerous stratifications that occurred over the centuries and not exactly datable.

The first castrense enclosure could be identified by the scarp sections in the north and west side of the current Farnese building, equipped with the crosspiece tower still visible today. The perimeter then had to be intersected and modified by building another tower to the west (Fig. 3), probably to balance a collapsed stretch of the primitive wall or to replace an existing flanking structure of the main gate of the village.

The prosperity of the west tower compared to the adjacent wall sections is confirmed by the differences in the width and in the development of the walls set in horizontal courses emphasized by putlog holes along with the apparecchi murari a cantieri, typically found in the Campana region, while the geometric regular course of the device and the conformation called cannocchiale of the tube refers to the thirtheenth century and Angevin era (Romalli, 2008, pp. 11-52). All this in a period where revision and modernization of the defense placement were located on the borders to the west and north of the kingdom. However, the castle of San Valentino does not appear in the Statutum de reparatione castrorum, nor does it appear in the Angiovina registry as a bas- 
tion subject to interventions of structural adjustments at the behest of the royal.

This might show that the west tower is considered to be the first core of a settled feudalism, a compact block, a scarp wall with defense garrisons on the sides that were mostly exposed to any foreign incomings and which also had a residential function. Next to the tower there is the chapel of Santi Valentino e Damiano and few service structures connected to the rest of the built-up area and to the subsequent rings of walls through the opening of the arch still present on the east side.

The passage from castrum to noble residence occurs with the weakening of the centre power in favour of the local feudalism, which had already occurred in Popoli and Pacentro, both initially subject to the county of Manoppello just like San Valentino. In the first two cases, given their political stability, it is simple to identify Cantelmo and Caldora as promoters of this transformation, respectively; San Valentino goes through the irregular fate of the families of Acquaviva, Orsini and Della Tolfa; it is only to the latter that a campaign of substantial modernization of the building can be traced with certainty, thanks to the epigraph found in the northern entrance hall dated 1507.

On the east volume there are the most interesting architectural features: the portal and the large hall on the ground floor characterized by diaphragm arches and mullioned window on the external wall of the upper volume. The entrance door, defined by piers that decorate alternating ashlars of different widths, appears as a simplified version of the typologies of the Durazzesca which was trialed in numerous civil construction works in Sulmona in the fourteenth and fifteenth century (Madonna, 2008, pp. 140-150).

The mullioned window, damaged by the recent earthquake in 2009, appears to have undergone an intervention of restoration; the external masonry of the upper volume where the window was placed in order to characterize the main front of the building overlooking the urban square revealed structural inadequacy in the 2009 earthquake: the stone bosses that completed the front, which was not appropriately clamped to elements placed at the headers with the core, was partially ejected from the plane causing the collapse of the mullioned window and the spiral column.

The quality of the walls clearly reveals the weakness of the load-bearing structures bringing the construction site to remedy by inserting antiseismic measures such as the wooden beam discovered during the consolidation works on the vault after the earthquake in 2009.

The instability of some buildings is also connected to the constant adaptations undergone to the original structure in response to the gradual transformation from fort to noble palace that was not yet completed in 1562 when it was described as a castle consisting of several elements, and a comfortable master tower ${ }^{2}$.

A heterogeneous structure that Margherita will unfortunately not be able to confer the dress of palace. However, the building, under the government of the Dukes of Parma (1583-1732) and of the Borbone, will welcome the Governors and authorities sent from Naples: it will be known as the "Rocca nel Palazzo"3.

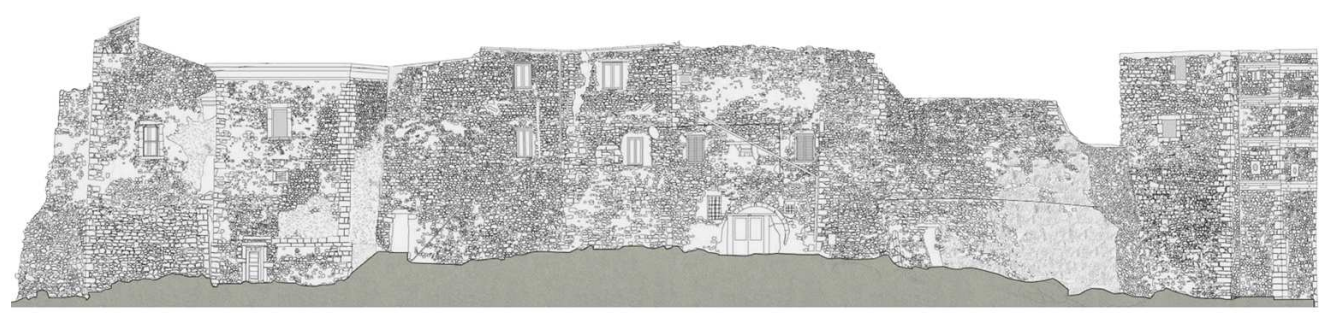

Fig. 3. San Valentino in Abruzzo Citeriore. The Farnese castle. West facade of the building (Author). 


\section{The churches of Santi Valentino e Damiano}

The current Mother church building rises on the site of a previous church, part of whose front was made of square-stones most likely belonging to the thirteenth century and still erected at the beginning of the nineteenth century. It is difficult to determine whether it was the religious building mentioned in the donations of the nineteenth century or a totally new construction. The earthquakes in 1703 and 1706 severely damaged the church; however, a restoration had never been promoted during the Farnesiano period ${ }^{4}$, and a new building was sponsored by the Borbone family as the Royal Church after having inherited San Valentino from Elisabetta Farnese.

It was in no case an obvious adjustment of the pre-existence to the Baroque language. The desire to provide the fief, being part of the Allodial States, of a Mother Church worthy of being counted among the personal possessions of the Crown and to whose worship the royals would seem to be strongly linked (Natarelli, 1990, pp. $245-246$ ), is at the origin of the construction whose dimensions and related technicalconstructive commitment result in a gradual process of reconstruction and adaptation that extends from mid-eighteenth century until almost mid-twentieth century.

1790 is the only date referable in relation to the beginning of the work ${ }^{5}$ and it is connected to the nineteenth century pastoral visit, however, it is significant to evaluate the persistence of the late Baroque language in Abruzzo and to frame the building site in a long-term perspective.

Built on the basis of a single project of Neapolitan origin ${ }^{6}$ or on the basis of experiments of regional origin, the Mother church building respects the position of the previous church, but follows a longitudinal development that exceeds the edge of the walls projecting the apse and the sacristy, built between 1844 and $1851^{7}$, beyond the perimeter of the ancient fortified village. On the other hand, the façade remained partially unfinished, flanked by the archpriest's house and clearly visible as far as the Pescara valley: only the portal was the result of the Baroque reconstruction, since the pre-existing medieval wall was visible.
The lack of certain documentary data on the construction site of the Mother Church leads to search affinities and similarities with other buildings designed or reconstructed following the numerous earthquakes that characterized Abruzzo in the eighteenth century.

The system in the juxtaposition of different space cells, nave, domed transept and deep apse, strengthen the longitudinal axis, but the spatial sequence finds in the insertion of a transverse span an interruption that anticipates the graft of the transept and allows the opening of the side entrances.

The presence of transversal spaces placed to mark the interpretation of the construction can be found in many examples in the Abruzzese Baroque: from San Filippo in L'Aquila, to San Francesco in Città Sant'Angelo. Moreover, in between the side chapels and smaller spaces in Santa Maria di Paganica in L'Aquila, or in the nearby parish church of Caporciano which presents a resolution of the main entrance that can be compared to that of Santi Valentino e Damiano.

The other religious buildings of the town are instead dimensionally and typologically distant. The hall of San Nicola da Tolentino represents in its eighteenth-century style the final phase of the evolution of the most ancient Augustinian monastery (Sigismondi, 2012), incorporated in the palaces of Olivieri de Cambacérès. The church of S. Donato is, instead, the object of an attempt to integrate the central and longitudinal scheme, as shown by the drawings preserved in the State Archives of Naples referred to an architect who calls himself "Giani", to be probably Giovan Battista Gianni ${ }^{8}$.

The series of substantial interventions of modernization and common revision of the historic center is completed by the new façade of the Mother Church, erected between 1916 and 1931. The visibility of the work, open on a vast panorama that allows it to be seen from afar, probably forced the designer Antonino Liberi to study solutions excessively expensive and monumental. 
The numerous requests for funding made by the parish Domenico Coia to the Ministry of Public Education ${ }^{9}$, combined with the views of the new building, are defined as improper by the Royal Superintendence of Monuments for Lazio and Abruzzo, which identifies a modern work of art in the imposing cut stone façade and therefore alien to the existing church. Along the same lines is the Deliberation of the Municipal Council of San Valentino on 15 July 1883, which authorizes the demolition of the archpriest house and replacing it with the new bell tower. ${ }^{10}$

A first version of the new façade appears as an evolution of themes already experimented by Liberi between 1897 and 1899 in the Torre Civica in Casalbordino: three orders of columns divide the façade into a sequence of niches, statues, balustrades and mixtilineal frames. Drafted by Liberi most likely after his stay in Rome (1915) (Di Tizio, 2009, p. 155), the definitive project drains out the previous solution in a rectangular horizontal shape framed by two twin bell towers.

In the four register façade, the succession of ashlar pilasters Mannerist-like style, Doric entablature with metopes and triglyphs, round arches on Ionic columns and window creates an episode that, beyond the obvious classical references, imposes to be, on the hand, part of the adjoining side according to the alleged Vanvitellian language, on the other hand, it is a visible solid landmark in a scenario that rises towards the Maiella Mountain.

\section{Conclusions}

The difficulty in drawing up universally efficient operative guidelines in the field of conservation and recovery of the historic centres along the Apennine ridge, which is once again confirmed by the contingencies of the reconstruction following the earthquake that hit L'Aquila in 2009 and the recent seismic events in central Italy, estimated by INGV (National Institute of Geophysics and Volcanology) in 23180 earthquakes revealed last year and still in progress- shows the importance to acknowledge and safeguard the values of identity related to specific territory contexts and the material culture associated.
The shape and the structure of the fortified buildings and the most ancient residential units in San Valentino, as in other historic centres in the Maiella, show the way to keep updated and give priority to properly recover the historic buildings. The curtain walls of the buildings are continuous architectural organisms designed to resist seismic events even through the aid of construction devices.

Studying and reviewing a building baggage which is deeply rooted in the territory at an experimental and operating practice level, such as that of the use of traditional cut stones and antiseismic garrison, represents the possibility to mitigate the need to improve the buildings responses when dealing with reiterating earthquakes often pursued with demolitions or with invasive and incompatible interventions with the historic buildings inevitably compromising the natural balance with the landscape and environmental context achieved by the historic centers.

\section{Notes}

${ }^{1}$ Archivio di Stato di Pescara (ASPe), Affari ecclesiastici, 1852-1860, lettera del Vicario all'Intendente di Chieti, 28 novembre 1852.

${ }^{2}$ Archivio Comunale di Penne, Acta super pertinentia iuris Patronatus Ecclesie Archipresbiterialis et aliorum beneficio rum et Cappellarum. Bacucco 1617. Nota di tutte l'intrate che sono in lo contado de San Valentino delle pruinzie di Apruzzo Citra et Ultra lo quale se fa per memoria dell' Illustrissimo S.or Carlo Moderno, cavato da li cunti visti per me Fabio de li Frangi de Palma nel mese di aprile 1562 in San Valentino.

3 Archivio di Stato di Napoli, Farnesiano, b. 1284, "Catasto de beni gentileschi fatto l'anno MDCXXXIX che si possede in territorio di san Valentino e Abbategia".

${ }^{4}$ Archivio Diocesano di Chieti, Visite pastorali, 1932, busta 561; ASPescara (ASPe), Governatorato, Affari comunali 1851-1861, fasc. I, busta 8 .

${ }^{5}$ Archivio Diocesano di Chieti, Visite pastorali, 1846, busta 542 .

${ }^{6}$ Archivio Diocesano di Chieti, Atti parrocchiali di s. Valentino, fasc. I, "Carte riguardanti il de- 
siderio di stabilirvi una chiesa ricettizia”, 17 ottobre 1831 .

${ }^{7}$ Archivio Diocesano di Chieti, Visite pastorali, 1846, busta 542 .

8 Archivio di Stato di Napoli, Farnesiano, b. 1299, fasc. 9.

9 Archivio Centrale dello Stato, Roma (ACS), Ministero della Pubblica Istruzione, Antichità e
Belle Arti, IV versamento, dispacci 21.05.1920, 25.08.1920, 15/03/1921.

${ }^{10}$ Archivio Storico Comunale, San Valentino in Abruzzo Citeriore, Libro delle Deliberazioni della Giunta Municipale 1883, dal 21 Marzo 1883 al 27 Ottobre 1884.

\section{Bibliography}

Chiarizia, G.; Latini, M. (2002). Atlante dei castelli d'Abruzzo. Repertorio sistematico delle fortificazioni, Carsa, Pescara.

Luzio, C. Di. (1990). Atti della vita e del martirio dei Santi Valentino e Damiano. Cenni storici sulla fondazione della città di San Valentino tradotti dal latino in lingua volgare, Chieti.

Madonna, A. (2008). "Edilizia civile a Sulmona nel quattrocento: la fortuna del portale durazzesco", in Pistilli, F.P. ed., Universitates e Baronie, Zip, Pescara.

Natarelli, A. (1990). "San Valentino", in Chiarizia, G. ed., Centri Storici della Val Pescara, dall'Evo Medio ai nostri giorni, Carsa, Pescara.

Romalli, G. (2008). "Da Guardigrele a Pacentro, dagli Orsini ai Caldora: castelli o residenze baronali?", in Pistilli, F.P. ed., Universitates e Baronie, Zip, Pescara.

Sigismondi, $\mathrm{M}^{\mathrm{a}}$.E. (2012). Eremi urbani: per una storia dell'architettura agostiniana in Abruzzo, Centro culturale agostiniano, Roma.

Sorricchio, L. (1929). "Hatria", in Atri. Dalle invasioni barbariche alla fine della dinastia Angioina, Pescara.

Tizio, F. Di. (2009). D'Annunzio e Antonino Liberi, carteggio 1879-1933, Ianier Ed., Pescara.

Varagnoli, C.; Serafini L. (2008). Abruzzo da salvare/1, Tinari, Villamagna.

Varrasso, A. (1992). Il territorio di San Valentino nell'alto medioevo, Vecchio Faggio, Chieti. 